\title{
Kepemimpinan kiai di pondok pesantren modern: Pengembangan organisasi, team building, dan perilaku inovatif
}

\author{
Devi Pramitha * \\ Manajemen Pendidikan Islam, Universitas Islam Negeri Maulana Malik Ibrahim. \\ Jl. Gajayana No. 50, Dinoyo, Lowokwaru, Malang, Jawa Timur 65144, Indonesia. \\ * Corresponding Author. E-mail: devipramitha@uin-malang.ac.id
}

\section{ARTICLE INFO \\ Article History \\ Received: \\ 7 July 2020; \\ Revised: \\ 13 August 2020; \\ Accepted: \\ 15 August 2020 \\ Available online: \\ 25 September 2020}

\section{Keywords}

Kepemimpinan kiai; Pengembangan organisasi;

Perilaku inovatif; Leadership of kiai; Organizational development; Team building; Innovative behavior

\begin{abstract}
Keberadaan sosok kiai sebagai pemimpin pondok pesantren memang sangat unik untuk selalu diteliti, hal tersebut dikarenakan dari sudut tugas dan fungsi seorang kiai yang tidak hanya sekedar memimpin, tetapi juga harus mampu mengembangkan organisasi pondok pesantren agar bisa tetap eksis di era globalisasi saat ini. Tujuan penelitian ini adalah untuk mengetahui gaya kepemimpinan kiai di pondok pesantren modern, yang dilihat dari tiga hal yaitu: 1.) Proses pengembangan organisasi; 2.) Proses pembentukan team building; dan 3.) Proses menumbuhkan perilaku inovatif. Penelitian ini menggunakan metode kualitatif dengan menggunakan pendekatan studi tokoh. Untuk proses pengumpulan data melalui wawancara, dokumentasi, dan observasi, sedangkan untuk analisis data menggunakan model Spradley yang terdiri dari 4 cara, yaitu: 1.) Analisis domain; 2.) Analisis taksonomi; 3.) Analisis komponensial; dan 4.) Analisis tema kultural. Dari hasil penelitian dapat diperoleh data, yaitu: 1.) Proses pengembangan organisasi dilakukan dengan cara memotivasi dan menginspirasi anggota bawahannya agar memiliki semangat yang tinggi dalam mengembangkan pondok pesantren; 2.) Proses pembentukan team building lebih banyak dilakukan melalui interaksi pola pikir; dan 3.) Proses menumbuhkan perilaku inovatif menggunakan cara dengan pendelegasian tugas-tugas.
\end{abstract}

The Kiai's existence as the leader in the Islamic boarding school is indeed very unique to always be researched. From the point of view of the duties and functions of a Kiai, who is not only leading but also must be able to develop the boarding school organization to continue to exist in the current era of globalization. The purpose of this study was to determine the leadership style of kiai in modern Islamic boarding schools, which was seen from three things, namely: 1.) The process of organizational development; 2.) The process of forming team building; and 3.) The process of fostering innovative behavior. This study uses a qualitative method using a character study approach. For the data collection process through interviews, documentation, and observation, while for data analysis using the Spradley model which consists of 4 ways, namely: 1.) Domain analysis; 2.) Taxonomic analysis; 3.) Component analysis; and 4.) Analysis of cultural themes. From the research results, data can be obtained, namely: 1.) The process of organizational development is carried out by motivating and inspiring subordinate members to have high enthusiasm in developing Islamic boarding schools; 2.) The process of forming team building is mostly done through mindset interactions; and 3.) The process of fostering innovative behavior by means of delegating tasks.

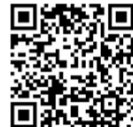

This is an open access article under the CC-BY-SA license.

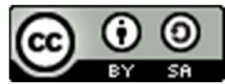

How to cite:

Pramitha, D. (2020). Kepemimpinan kiai di pondok pesantren modern: Pengembangan organisasi, team building, dan perilaku inovatif. Jurnal Akuntabilitas Manajemen Pendidikan, 8(2), 147-154. doi: https://doi.org/10.21831/jamp.v8i1.33058 


\section{PENDAHULUAN}

Keberadaan pondok pesantren baik yang masih mempertahankan sistem pendidikan tradisional maupun yang sudah mengalami perubahan, memiliki pengaruh besar dalam kehidupan masyarakat Indonesia (Siswanto, 2015). Oleh karena itu, keberadaan sosok kiai sebagai pemimpin pondok pesantren merupakan salah satu khazanah keilmuan yang menyimpan magis tersendiri untuk selalu dikaji dari berbagai aspek dan sudut pandang. Kedudukan kiai menjadi unsur terpenting dalam pesantren dalam kapasitasnya sebagai perancang (arsitektur), pendiri dan pengembang (developer), sekaligus sebagai seorang pemimpin dan pengelola (leader and manager) pesantren (Mardiyah, 2013). Bahkan kepemimpinan kiai jika ditinjau dari tugas dan perannya sangat komplek yaitu sebagai pelopor, penggerak keseluruhan aktivitas pesantren, pendidik dan peserta aktif dalam menangani berbagai persoalan social masyarakat (Dhofier, 2011).

Kiai sendiri merupakan central figure setiap pondok pesantren. Central figure kiai bukan saja karena keilmuannya, melainkan juga karena kiai lah yang menjadi pendiri, pemilik dan pewakaf pesantren itu sendiri, perjuangannya tak terbatas pada ilmu, tenaga, waktu tetapi juga tanah dan materi lainnya diberikan demi kemajuan syiar Islam (Suharto, 2011). Disamping itu, kiai pesantren dipandang kharismatik oleh masyarakat dan tidak boleh digugat juga menjadi variable penentu ketahanan pesantren, dalam kedudukan seperti itu kiai dapat juga disebut agent of change dalam masyarakat yang berperan penting dalam suatu proses perubahan sosial. Berangkat dari teori tersebut dapat disimpulkan bahwa kiai berperan terhadap ketahanan pesantren selain daripada akomodasi pesantren terhadap perubahan, keterkaitan pesantren dengan komunitas lingkungannya dan posisi kharismatik Kiai sebagai pimpinan pesantren (Anwar, 2011).

Kepemimpinan sendiri selalu berhubungan dengan sistem sosial kelompok maupun individu. Dalam upaya mewujudkan kepemimpinan yang efektif, maka kepemimpinan harus dijalankan sesuai dengan fungsinya. Wirawan (2013) dalam bukunya kepemimpinan teori, psikologi, perilaku organisasi, aplikasi dan penelitian menyatakan beberapa fungsi kepemimpinan sebagai berikut: 1.) Menciptakan visi; 2.) Mengembangkan budaya organisai; 3.) Menciptakan sinergis; 4.) Memciptakan perubahan; 5.) Memotivasi para pengikut; 6.) Memberdayakan pengikut; 7.) Mewakili sistem sosial; 8.) Manajer konflik; dan 9.) Memberlajarkan organisasi (Wirawan, 2013).

Di dalam perkembangannya, memang pondok pesantren tidaklah semata-mata kemudian tumbuh secara stagnan dalam artian selalu berada atas pola lama yang bersifat tradisional, melainkan bisa dilakukan suatu inovasi dalam pengembangan lembaga pondok pesantren tersebut. Modernisasi yang dalam bentuk umum Indonesia lebih dikenal dengan istilah pengembangan (development) yaitu sebuah proses multidimensional yang komplek. Dalam lapangan pendidikan, modernisasi setidaknya dapat dilihat dengan direalisasikannya pembentukan lembaga-lembaga pendidikan modern yang mengadopsi dari sistem dan kelembagaan kolonial Belanda, bukan dari sistem pendidikan Islam tradisional (Baharun, 2013). Meskipun belum terdapat kesepakatan bulat tentang tipologi kepemimpinan yang secara luas, dewasa ini dikenal lima tipe kepemimpinan yang diakui keneradaannya, yaitu : 1.) Tipe otokratik; 2.) Tipe paternalistik; 3.) Tipe kharismatik yang terbagi menjadi tipe Laissez Faire dan tipe demokratik; 4.) Tipe kepemimpinan transformasional yang dikembangkan oleh Benard M. Bass; dan 5.) Tipe kepemimpinan transaksional yang dikembangkan oleh James MacGregor Burns (Siagian, 2010).

Secara konseptual, kepemimpinan transformasional didefinisikan sebagai kemampuan pemimpin mengubah lingkungan kerja, motivasi kerja, dan pola kerja, nilai-nilai kerja yang dipersepsikan bawahan, sehingga mereka lebih mampu mengoptimalkan kinerja untuk mencapai tujuan organisasi. Pemimpin juga mentransformasikan harapan untuk suksesnya pengikut, serta nilai-nilai, dan mengembangkan budaya organisasi untuk mencapai tujuan yang ditetapkan pemimpin. Melalui kepemimpinan transformasional pengikut dapat mencapai kinerja yang melebihi yang telah diharapkan pemimpin (performance beyond expetation) (Wirawan, 2013). Menurut pandangan Bass dalam Ancok (2012), terdapat empat hal yang menjadi ciri pemimpin transformasional, yaitu: 1.) Pengaruh yang diidealkan (idealized influence), yaitu sifat-sifat yang dikagumi pengikut dari pemimpinnya. Perwujudan sifat keteladanan antara lain adalah memberi contoh bagaimana dia berperilaku dalam melayani orang lain, khususnya dalam melayani karyawan sebagai mitra kerjanya.; 2.) Stimulasi intelektual (intellectual stimulation), yaitu proses merangsang pemikiran 
kreatif dan gagasan inovatif dalam diri pengikut; 3.) Kepedulian secara perorangan adalah ciri pemimpin yang memperhatikan kebutuhan karyawannya dan membantu karyawan agar mereka bisa maju dan berkembang dalam karir dan kehidupan mereka; dan 4.) Motivasi yang inspiratif adalah sifat pemimpin yang memberikan inspirasi dalam bekerja, mengajak karyawan untuk mewujudkan sebuah cita-cita bersama agar hidup dan karya mereka menjadi bermakna.

Kiai H. Achmad Zamachsyari atau yang lebih dikenal dengan sebutan Gus Mad adalah salah satu inisiator untuk melakukan perubahan dengan mengembangkan pondok pesantren modern di kota Malang. Inisiatif itulah yang kemudian menjadikan beliau menjadi seorang pemimpin, dimana beliau harus memberikan visi, haluan kepada orang lain untuk beranjak dan bergerak dari tempat semula menuju perbaikan dan perubahan. Sejatinya kiai H. Achmad Zamachsyari tidak hanya ingin mendirikan pondok pesantren modern saja di desa Ketawang, tetapi juga ingin membangun dan mengubah mental para penghuninya dari keterbelakangan. kiai H. Achmad Zamachsyari yakin dengan konsep perubahan yang dilakukan dirinya akan berhasil, walaupun pada saat itu banyak orang yang tidak yakin jika pondok pesantren modern yang akan didirikan akan memiliki banyak santri. Akhirnya selama hampir empat tahun lamanya, Kiai H. Achmad Zamachsyari mampu mendirikan Yayasan Pondok Modern Al-Rifa'ie.

Kepemimpinan kiai H. Achmad Zamachsyari dalam mengembangkan pondok pesantren menunjukkan bahwa di era globalisasi saat ini, pondok pesantren juga menghadapi perubahan seiring dengan perkembangan akan kebutuhan masyarakat, dan tentunya fenomena tersebut menuntut adanya peran kiai sebagai seorang pemimpin pondok pesantren harus bisa menjadi agent of change sekaligus dituntut sebagai keeping a cultural life (memilihara kehidupan budaya) agar tidak kehilangan karakter kelembagaannya. Dari konteks penelitian tersebut dapat disimpulkan bahwa kiai sebagai pemimpin pondok pesantren sangat dibutuhkan dan menjadi pucuk penyebab keberhasilan maupun kegagalan suatu organisasi. Dalam hal ini kiai H. Achmad Zamachsyari sebagai seorang kiai tidak hanya menggunakan gaya kepemimpinan kharismatik saja tetapi juga menggunakan gaya kepemimpinan demokratis dan transformasionalisme yang dilakukan melalui tiga pendekatan, yaitu pengembangan organisasi, team building, dan perilaku inovatif.

\section{METODE}

Penelitian ini merupakan suatu penelitian yang dapat dikategorikan sebagai penelitian kualitatif, karena penelitian ini memahami tingkah laku partisipan, mendeskripsikan latar, mendeskripsikan interaksi yang kompleks, dan mendeskripsikan fenomena yang terjadi. Dalam implementasinya, penelitian ini dilakukan dengan menggunakan pendekatan biografi atau studi tokoh, dengan alasan antara lain: 1.) Karena peneliti memfokuskan diri pada satu orang individu, membangun penelitian dari cerita dan kejadian-kejadian spesial kemudian menempatkannya dalam konteks yang lebih luas, serta membangkitkan keberadaan peneliti dalam penelitian tersebut (Almanshur, 2012); 2.) Karena biografi atau studi tokoh merupakan studi terhadap seseorang atau individu untuk memahami perilaku dan pola interaksi manusia dengan lingkungannya melalui proses kepemimpinannya atas keinginan peneliti sendiri.

Dalam pelaksanaannya, yang menjadi fokus penelitian adalah kehidupan secara keseluruhan atau kehidupan hanya dalam beberapa fase dari seorang individu yang dianggap unik khas, menarik, atau dianggap luar biasa, sehingga layak untuk diangkat menjadi suatu penelitian dengan pendekatan kualitatif (Herdiansyah, 2010). Oleh karena itu, peneliti mencoba untuk memperoleh data informasi selengkap mungkin terkait kepemimpinan kiai H. Achmad Zamachsyari, sehingga tidak terbatas pada komunitas di pondok pesantren saja melainkan juga komunitas yang ada di luar pondok pesantren. Dalam penelitian kualitatif yang menggunakan pendekatan studi tokoh pada umumnya menggunakan tiga metode pengumpulan data, yaitu wawancara, dokumentasi, dan observasi. Adapun proses analisis data, peneliti menggunakan model analisis data yang digagas oleh Spradley yang terdiri dari 4 cara, yaitu: 1.) Analisis domain; 2.) Analisis taksonomi; 3.) Analisis komponensial; dan 4.) Analisis tema kultural. Uji keabsahan data dalam penelitian kualitatif meliputi uji credibility (validitas internal), transferability (validitas eksternal), dependability (reliabilitas) dan confirmability (obyektivitas). 


\section{HASIL DAN PEMBAHASAN}

Hasil

Kiai di dalam dunia pesantren berperan sebagai penggerak dalam mengemban dan mengembangkan pesantren. Kiai bukan hanya pemimpin pondok pesantren tetapi juga pemilik pondok pesantren. Dengan demikian kemajuan dan kemunduran pondok pesantren benar-benar terletak pada kemampuan kiai dalam mengatur pelaksanaan pendidikan di dalam pesantren. Hal ini disebabkan karena besarnya pengaruh seorang kiai dan juga tidak hanya terbatas dalam pesantrennya, melainkan juga terhadap lingkungan masyarakatnya (Ghazali, 2002). Proses transformasi sosio-kultural yang berlangsung dewasa ini hampir menjamah ke setiap sudut kehidupan masyarakat. Pondok pesantren yang sering disebut-sebut sebagai lembaga pendidikan tertua yang menjaga nilai-nilai tradisionalnya pun tidak lepas dari jangkauan proses tersebut. Meski demikian pondok pesantren mampu mengembangkan organisasinya agar tetap bertahan atau survive di perkembangan zaman yang semakin besar tuntutannya ini. Keberhasilan pondok pesantren dalam perjalanan transformasi sosio-kultural yang dilaluinya tidak lepas dari peran kepemimpinan kiai di dalamnya.

Selain melakukan pendekatan pengembangan organisasi, kiai sebagai pemimpin pesantren dalam menggerakkan semua komunitas yang ada di pondok pesantren memakai pendekatan team building. Hal ini tampak dalam interaksi baik antara kiai, ustadz atau ustadzah maupun para santri. Dalam memimpin YPM Al-Rifa'ie, kiai H. Achmad Zamachsyari senantiasa berusaha untuk menyeimbangkan interaksi antara kiai dengan komunitas pondok pesantrennya, baik komunitas internal (santri dan guru atau asatidz) maupun komunitas eksternal (masyarakat), melalui interaksi fisik, interaksi pola pikir, dan interaksi ruh atau batin. Dengan demikian baik para santri, guru atau asatidz, staf maupun masyarakat, dapat ikut berperan aktif serta dalam mengembangkan pondok pesantren sebagai pelaku perubahan (agent of change) dalam berbagai aspek kehidupan.

Adanya team building antara pimpinan dan bawahan merupakan salah satu bagian penting bagi setiap organisasi, termasuk organisasi yang ada di pondok pesantren. Walaupun pimpinan pondok pesantren adalah seorang kiai, namun bukan berarti harus menutup diri dengan bawahannya, sebaliknya kiai harus sering melakukan interaksi tidak hanya dengan komunitas internal pondok pesantren saja, namun dengan komunitas eksternal pondok pesantren juga perlu dilakukan. Hal itu senada dengan teori interaksi (interaction theory) yang pada prinsipnya sama dengan kontingensi (contingency theory) dari Fiedler dan expectancy-reinforcement theory dari Stogdill (Saefullah, 2012). Dimana teori interaksi ini berasumsi bahwa semakin sering terjadi interaksi dan partisipasi dalam kegiatan bersama, semakin meningkat pula perasaan saling menye-nangi satu sama lain dan saling memperjelas pengertian atas norma kelompok (Saefullah, 2012).

Interaksi fisik yang dilakukan oleh kiai $\mathrm{H}$. Achmad Zamachsyari terhadap santri akan memunculkan sikap tawaddu santri terhadap kiai dan memunculkan istilah ngalap barokah yang artinya santri akan menuruti apa saja yang dikatakan dan diperintahkan oleh kiai H. Achmad Zamachsyari guna mengharap barakah ilmu yang dipelajarinya di pondok pesantren. Sedangkan interaksi pola pikir yang dilakukan oleh kiai $\mathrm{H}$. Achmad Zamachsyari terhadap anggota bawahannya, juga interaksi ruh yang dilakukannya kepada masyarakat akan memunculkan sikap ketaatan, kesetian, dan kepatuhan (loyalitas) yang tinggi dari anggota bawahan maupun masyarakat terhadap kiai dan pondok pesantren. Hal itu senada dengan gaya kepemimpinan tradisional yang dipaparkan oleh Weber bahwa dalam kepemimpinan tradisional, kepatuhan diberikan kepada orang atau pemimpin yang menduduki kekuasaan tradisional yang terikat pula dalam suasana tersebut. Pengikut patuh pada pimpinan tidak didasarkan pada tatanan impersonal, tetapi menjadi loyalitas pribadi dalam ruang lingkup dengan membiasakan tunduk pada kewajiban.

Dari kedua pendekatan tersebut, salah satu langkah yang penting untuk melaksanakan perubahan ialah dengan memperkuat perilaku inovatif kepada anggota, kelompok dan organisasi itu sendiri. Begitu pula dengan pemberian imbalan (reward) memberi motivasi dan reinformasi (penegakan kebijaksanaan), sehingga terdapat nuansa ganda, yaitu: kebanggaan, semangat kerja, dan tanggung jawab juga merupakan langkah yang penting dalam mewujudkan perilaku inovatif. Sebagai seorang pemimpin pondok pesantren, kiai $\mathrm{H}$. Achmad Zamachsyari mengemban amanah yang besar dalam mengelola pondok pesantren. Namun hal itu bukan berarti kiai H. Achmad Zamachsyari adalah satu-satunya orang yang menentukan arah kebijakan dan pengembangan pondok pesantren.

Volume 8, No. 2, September 2020 
Manajemen di YPM Al-Rifa'ie hampir semuanya dikendalikan oleh para pengurus atau anggota bawahannya (guru dan staf), sehingga dalam proses pengelolaan pondok dapat memunculkan perilaku inovatif para bawahannya baik itu bersifat manajerial maupun non manajerial. Perilaku inovatif yang bersifat manajerial artinya, perilaku inovatif yang terkait dengan urusan kelembagaan, sedangkan perilaku inovatif non manajerial yaitu perilaku inovatif yang tidak terkait dengan urusan kelembagaan. Perilaku inovatif yang demikian dilakukan oleh kiai H. Achmad Zamachsyari dalam rangka ingin mengembangkan potensi bawahannya dengan tetap menjaga otoritasnya sebagai pemimpin pondok pesantren.

Pembahasan

\section{Pengembangan Organisasi di YPM Al-Rifa'ie}

Pengembangan organisasi adalah sebuah sistem aplikasi luas dan transfer pengetahuan ilmu perilaku ke rencana pengembangan, peningkatan, penguatan strategi, struktur, dan proses yang mengarah pada efektifitas organisasi (Cummings, 2014). Definisi ini secara jelas menekankan bahwa tujuan akhir dari pengembangan organisasi adalah terwujudnya efektivitas organisasi. Pada dasarnya pengembangan organisasi penting untuk dilakukan karena mengarah pada peningkatan efektifitas organisasi dengan tujuan mengupayakan perbaikan kemampuan organisasi dalam menyesuaikan diri terhadap perubahan lingkungan serta perubahan perilaku anggota organisasi (Robbins \& Judge, 2014). Oleh karena itu, kiai H. Achmad Zamachsyari sebagai pemimpin di YPM Al-Rifa'ie melakukan perubahan yang terencana untuk keseluruhan perangkat maupun sistem, struktur, budaya, dinamika kelompok, kualitas SDM, strategi pemasaran, dan lain sebagainya agar pondok pesantren yang dipimpinnya dapat menjadi organisasi yang efektif. Adanya sosok kiai sebagai pemimpin pondok pesantren menjadi salah satu faktor yang sangat menentukan kesuksesan pondok pesantren.

Dalam melakukan pengembangan organisasi kiai H. Achmad Zamachsyari melakukan beberapa perilaku, yaitu: Pertama, kiai H. Achmad Zamachsyari mampu menjadikan dirinya sebagai sosok pemimpin yang ideal di mata para bawahan melalui kharisma yang dimilikinya. Kharisma tersebut terlihat dari segi keilmuan yang dimiliki oleh kiai H. Achmad Zamachsyari, baik ilmu natural maupun supranatural. Selain itu sebagai seorang pemimpin kiai H. Achmad Zamachsyari memiliki ide besar, yakni melakukan modernisasi pendidikan pesantren, yang didorong oleh keyakinan dan niat kuat dalam mewujudkanya, serta komitmen dan konsisten dalam proses pelaksanaannya. Kedua, sebagai seorang pimpinan pondok pesantren, kiai H. Achmad Zamachsyari piawai dalam memotivasi dan menginspirasi anggota bawahannya untuk memiliki semangat yang tinggi dalam mengembangkan pondok pesantren. Beberapa strategi yang dilakukan oleh kiai H. Achmad Zamachsyari, antara lain: 1.) Menjadikan dirinya sebagai uswatun hasanah atau teladan yang baik bagi para bawahannya; 2.) Memberikan reward atau penghargaan bagi anggota bawahannya yang melakukan pekerjaan dengan baik; 3.) Selalu mengadakan muhasabah bersama setiap bulan dalam rangka menuju perubahan dan perbaikan serta menjadi salah satu media komunikasi kiai $\mathrm{H}$. Achmad Zamachsyari dengan semua anggota bawahannya.

Ketiga, meskipun kiai H. Achmad Zamachsyari merupakan pendiri dan pemilik YPM AlRifa'ie, namun tidak menjadikan dirinya sebagai seorang pemimpin tunggal yang otoriter terhadap bawahannya. Menginginkan suasana organisasi yang demokratis, kiai H. Achmad Zamachsyari pun memberikan kewenangan yang ada pada dirinya kepada semua anggota bawahan melalui cara pendelegasian tugas-tugas. Hal tersebut dilakukan sebagai sebuah stimulus bagi bawahannya untuk dapat mengembangkan potensi yang dimilikinya secara bebas dalam rangka mencapai visi dan misi pondok pesantren. Keempat, sebagai seorang pemimpin dan juga seorang kiai, kiai H. Achmad Zamachsyari mampu memberikan perhatiannya terhadap bawahannya baik secara individu maupun bersama-sama. Secara individu dilakukan oleh kiai H. Achmad Zamachsyari melalui diskusi empat mata dan bertukar pikiran baik menyangkut persoalan pondok pesantren maupun persoalan pribadi. Sedangkan untuk memberi perhatian kepada semua anggota bawahannya kiai H. Achmad Zamachsyari selalu mengadakan pertemuan di kediamannya setiap akhir bulan dan mengadakan acara yang melibatkan seluruh guru dan staf yang ada di YPM Al-Rifa'ie. Dengan beberapa perilaku kepemimpinan kiai H. Achmad Zamachsyari tersebut ternyata mampu menjadikan YPM Al-Rifa'ie berkembang cukup pesat dan cepat. Dengan perilaku tersebut dapat menumbuhkan semangat pada 
anggota bawahannya untuk tercapainya visi dan misi pondok pesantren, serta dapat mengembangkan organisasi lebih baik lagi.

\section{Pendekatan Team Building di YPM Al-Rifa'ie}

Team building dapat dipahami sebagai proses yang terdiri dari kegiatan formal yang dimaksudkan untuk meningkatkan pengembangan dan fungsi tim kerja (McShane, Von Glinow, \& Von Glinow, 2018). Jones (2013) menjelaskan bahwa salah satu bentuk team building adalah mengklarifikasi peran. Selama ini banyak orang beranggapan bahwa sebuah tim tidak ada bedanya dengan kelompok, padahal di antara kedua-nya memiliki perbedaan yang sangat signifikan. Dalam sebuah kelompok biasanya hubungan yang dibangun hanya sebatas berinteraksi untuk membagi informasi dan mengambil keputusan untuk membantu tiap anggota dalam bidang yang menjadi tanggungjawabnya. Sedangkan tim kerja meru-pakan kelompok yang upaya-upaya individunya menghasilkan suatu kinerja yang lebih besar dari-pada jumlah dari masukan-masukan individual (Fachry, 2015).

Kesalahan pandangan inilah yang kemudian berimplikasi terhadap kinerja tim dalam menjalankan tugas-tugasnya, sehingga tidak jarang masih banyak tim-tim yang dibangun tidak bisa menjelma menjadi sebuah tim yang solid karena dalam pelaksanaannya masih cenderung bersifat kelompok. Untuk mewujudkan team building yang kuat maka kiai $\mathrm{H}$. Achmad Zamachsyari melakukan beberapa bentuk interaksi, diantaranya adalah: Pertama, dalam berinteraksi dengan para santri, kiai H. Achmad Zamachsyari menjadikan dirinya tidak hanya sebagai seorang guru, namun juga sebagai sosok ayah kepada anak-anaknya yang patut diteladani dan dijadikan panutan. Dalam hal ini kiai $\mathrm{H}$. Achmad Zamachsyari melakukan interaksi fisik, yang artinya selalu menghadirkan dirinya ditengah-tengah para santri di setiap acara, serta memberikan peluang interaksi yang bersifat edukatif-demokratis selama 24 jam. Kebanyakan dalam berinteraksi dengan para santri, kiai $\mathrm{H}$. Achmad Zamachsyari lebih banyak memberikan motivasi melalui mauidhoh hasanah kepada mereka untuk selalu semangat dalam mencari ilmu di pondok pesantren. Selain itu kiai H. Achmad Zamachsyari juga menggunakan pendekatan motivasi penteladanan (uswah), misalnya memberikan contoh kepada santrinya dengan senantiasa shalat lima waktu berjamaah secara istiqamah (continual), sehingga dengan adanya interaksi yang akrab antara kiai dengan santri, menunjukkan bahwa kiai sebagai pengasuh pondok pesantren memberikan peluang untuk intensifikasi pendidikan.

Kedua, interaksi kiai H. Achmad Zamachsyari dengan bawahannya yang dalam hal ini meliputi guru, asatidz, pengurus, serta staf dilakukan melalui interaksi pola pikir. Sebagai seorang pemimpin di YPM Al-Rifa'ie, kiai H. Achmad Zamachsyari tidak pernah mengabaikan saran dari bawahannya, sehingga dalam proses pelaksanaan program di YPM Al-Rifa'ie, kiai H. Achmad Zamachsyari selalu mengajak bawahannya untuk bertukar pikiran dan berdiskusi terlebih dahulu. Hal tersebut merupakan salah satu bangunan interaksi yang berkelanjutan dengan maksud agar mereka dapat merasa menjadi bagian dari pondok pesantren. Interaksi tersebut dilakukan setiap saat secara individu, karena kiai H. Achmad Zamachsyari sendiri lebih suka diskusi secara empat mata, namun ada kalanya kiai $\mathrm{H}$. Achmad Zamachsyari berinteraksi dengan semua anggotanya yang dilakukan pada pertemuan rutin setiap akhir bulan untuk melakukan muhasabah dan juga pemberian motivasi.

Ketiga, selain melakukan interaksi dengan komunitas internal pondok pesantren, kiai $\mathrm{H}$. Achmad Zamachsyari juga melakukan interaksi dengan komunitas eksternal pondok pesantren yang dalam hal ini adalah masyarakat. Interaksi ruh yang dilakukan oleh kiai H. Achmad Zamachsyari kepada masyarakat melalui kegiatan-kegiatan spiritual seperti: istighosah bersama, sholat hajat, maupun acara keagamaan lainnya yang merupakan salah satu media kiai untuk berinteraksi dengan masyarakat. Mengingat masyarakat desa Ketawang khususnya merupakan masyarakat yang terkenal dengan keterbelakangan, baik dari segi ekonomi maupun pemahaman terhadap agama, maka kiai $\mathrm{H}$. Achmad Zamachsyari bertugas untuk melakukan perubahan sosial dengan memberikan pengaruh yang kuat di tengah-tengah masyarakat. Berbekal kedalaman ilmu agama yang diimbangi dengan pola hidup yang merakyat, serta kharisma yang tinggi dan selalu memberikan bantuan kepada orang yang membutuhkan, membuat masyarakat mendukung kegiatan spiritual yang diadakan oleh kiai $\mathrm{H}$. Achmad Zamachsyari. 


\section{Pendekatan Perilaku Inovatif di YPM Al-Rifa'ie}

Perilaku inovatif didefinisikan sebagai keseluruhan tindakan individu yang mengarah pada pemunculan, pengenalan dan penerapan dari sesuatu yang baru dan menguntungkan pada seluruh tingkat organisasi (Kresnandito \& Fajrianthi, 2012). Perilaku inovatif juga salah satu faktor yang mempengaruhi kinerja (Leong \& Rasli, 2014), sehingga kiai H. Achmad Zamachsyari dalam memimpin YPM Al-Rifa'ie akan berupaya memecahkan permasalahan (mencari problem solving) dengan menggunakan cara yang berbeda dengan biasa orang lakukan tetapi akan menghasilkan efektif dan efisien. Perilaku ino-vatif yang dilakukan secara terstruktur dan sistematis membutuhkan komitmen, keterlibatan, dan kepemimpinan manajemen dalam mengembangkan faktor penunjang yang bersifat terknikal maupun non teknikal yang mampu mendorong perilaku inovatif dalam setiap peran pekerjaan. Dalam pema-haman praktis, perilaku kerja inovatif merupakan kontinum perilaku yang melibatkan proses berfikir kreatif (intrapersonal) hingga meyakinkan orang lain (interpersonal) dalam setiap pelaksanaan ide pada situasi pekerjaan (De Jong \& Den Hartog, 2010).

Kiai H. Achmad Zamachsyari dalam memimpin YPM Al-Rifa'ie tidak pernah memperlakukan dirinya sebagai pemimpin tunggal di pondok. Beliau menginginkan pondok ini menjadi organisasi yang demokratis, dalam artian kiai H. Achmad Zamachsyari selalu memberikan kesempatan yang luas kepada para bawahannya untuk mengembangkan pondok ini sendiri sesuai dengan kemampuan yang mereka miliki. Dalam menggunakan pendekatan perilaku inovatif kiai H. Achmad Zamachsyari selalu menggunakan cara dengan pendelegasian tugas-tugas, sehingga kiai H. Achmad Zamachsyari hanya memberikan arahan bagaimana mereka harus bertindak sesuai dengan visi dan misi yang diharapkan bersama. Begitu juga dalam membuat suatu peraturan atau kebijakan kiai $\mathrm{H}$. Achmad Zamachsyari selalu melibatkan beberapa orang bawahannya. Namun dalam proses musyawarah kiai $\mathrm{H}$. Achmad Zamachsyari lebih sering diam karena ingin memberikan kesempatan kepada bawahannya untuk mengeluarkan ide-ide inovatif yang dipunya, sehingga kiai H. Achmad Zamachsyari hanya berperan diakhir untuk menyetujui atau menolak hasil yang telah diskusikan secara bersama atau mufakat.

\section{SIMPULAN}

Proses pengembangan organisasi di YPM Al-Rifa'aie dilakukan melalui beberapa perilaku, yaitu: 1.) Kiai H. Achmad Zamachsyari mampu menjadikan dirinya sebagai sosok pemimpin yang ideal di mata para bawahan melalui kharisma yang dimilikinya; 2.) Sebagai seorang pimpinan pondok pesantren, Kiai H. Achmad Zamachsyari piawai dalam memotivasi dan menginspirasi anggota bawahannya untuk memiliki semangat yang tinggi dalam mengembangkan pondok pesantren; 3.) Kiai H. Achmad Zamachsyari tidak menjadikan dirinya sebagai seorang pemimpin tunggal yang otoriter terhadap bawahannya; dan 4.) Kiai H. Achmad Zamachsyari mampu memberikan perhatiannya terhadap bawahannya baik secara individu maupun bersama-sama. Proses pembentukan tim building di YPM Al-Rifa'ie dilakukan melalui interaksi Kiai H. Achmad Zamachsyari dengan bawahannya yang dalam hal ini meliputi guru, asatidz, pengurus, serta para staf dengan cara interaksi pola pikir. Hal tersebut merupakan salah satu bangunan interaksi yang berkelanjutan dengan maksud agar mereka dapat merasa menjadi bagian dari pondok pesantren. Proses menumbuhkan perilaku inovatif di YPM Al-Rifa'ie menggunakan cara dengan pendelegasian tugas-tugas, sehingga Kiai $\mathrm{H}$. Achmad Zamachsyari hanya memberikan arahan bagaimana mereka harus bertindak sesuai dengan visi misi yang diharapkan bersama. Dari ketiga hal tersebut terlihat bahwa Kiai H. Achmad Zamachsyari menggabungkan gaya kepemimpinan transformasionalisme dengan gaya kepemimpinan demokratis dengan tetap berpegang prinsip pada al-Muhafadzatu 'ala qadimi as-salih wa al-akhdu bi al-jadidi al-aslah.

\section{DAFTAR PUSTAKA}

Almanshur, D. G. (2012). Metode penelitian kualitatif. Yogjakarta: Ar-Ruzz Media.

Ancok, D. (2012). Psikologi kepemimpinan \& inovasi. Jakarta: Erlangga. 
154 - Jurnal Akuntabilitas Manajemen Pendidikan

Anwar, A. (2011). Pembaharuan pendidikan di pesantren Lirboyo Kediri. Yogyakarta: Pustaka Belajar.

Baharun, H. (2013). Transformasi kelembagaan pendidikan pondok pesantren. Retrieved from https://www.nu.or.id/post/read/44962/transformasi-kelembagaan-pendidikan-pondokpesantren

Cummings, T. G. (2014). Organization development and change $\left(9^{\text {th }}\right.$ ed.). Canada: Cengage Learning.

De Jong, J., \& Den Hartog, D. (2010). Measuring innovative work behaviour. Creativity and Innovation Management, 19(1), 23-36. doi: https://doi.org/10.1111/j.14678691.2010.00547.x

Dhofier, Z. (2011). Tradisi pesantren studi pandangan hidup kyai dan visinya mengenai masa depan Indonesia. Jakarta: LP3ES.

Fachry, F. (2015). Pengembangan organisasi melalui team building, kompetisi dan kerjasama. Pedagogik: Jurnal Pendidikan, 2(1). doi: https://doi.org/10.33650/pjp.v2i1.104

Ghazali, B. (2002). Pesantren berwawasan lingkungan. Jakarta: CV Prasasti.

Herdiansyah, H. (2010). Metodologi penelitian kualitatif untuk ilmu-ilmu sosial. Jakarta: Salemba Humanika.

Jones, G. R. (2013). Organizational theory, design, and change ( $7^{\text {th }}$ ed.). London: Pearson Education.

Kresnandito, P. A., \& Fajrianthi, F. (2012). Pengaruh persepsi kepemimpinan transformasional terhadap perilaku inovatif penyiar radio. Jurnal Psikologi Industri dan Organisasi, 1(2), 96103. Retrieved from http://journal.unair.ac.id/filerPDF/jpio0a4a20119d2full.pdf

Leong, C. T., \& Rasli, A. (2014). The relationship between innovative work behavior on work role performance: An empirical study. Procedia-Social \& Behavioral Sciences, 129, 592-600. doi: https://doi.org/10.1016/j.sbspro.2014.03.717

Mardiyah, M. (2013). Kepemimpinan kiai dalam memelihara budaya organisasi. Yogyakarta: Aditya Media Publishing.

McShane, S. L., Von Glinow, M. A. Y., \& Von Glinow, M. A. (2005). Organizational behavior. New York, NY: McGraw-Hill Irwin.

Robbins, S. P., \& Judge, T. A. (2014). Perilaku Organisasi (organizational Behavior) (12 ${ }^{\text {th }}$ ed.). Jakarta: Salemba Empat.

Saefullah, S. (2012). Manajemen pendidikan Islam. Bandung: CV Pustaka Setia.

Siagian, S. P. (2010). Teori \& praktek kepemimpinan. Jakarta: Rineka Cipta.

Siswanto, S. (2015). Desain Mutu Pendidikan Pesantren. KARSA: Journal of Social and Islamic Culture, 23(2), 259-275. doi: https://doi.org/10.19105/karsa.v23i2.726

Suharto, B. (2011). Dari pesantren untuk umat. Surabaya: Imtiyaz.

Wirawan, W. (2013). Kepemimpinan teori, psikologi, perilaku organisasi, aplikasi dan penelitian. Jakarta: Raja Grafindo Persada. 